УДК 336.7

DOI: https://doi.org/10.54929/pmt-issue2-2021-10

\title{
ДИВЕРСИФІКАЦІЯ БАНКІВСЬКИХ ПОСЛУГ: СВІТОВИЙ ДОСВІД
}

\section{DIVERSIFICATION OF BANKING SERVICES: WORLD EXPERIENCE}

Островська Н. С.

д.е.н., доцент,

доцент кафедри публічних, корпоративних фрінансів та фінансового посередництва,

Чернівецький національний університет імені Юрія Федьковича ORCID ID: 0000-0002-7259-7403

Васечкіна В. 0. здобувачка вищої освіти 6 курсу спеціальності «Фінанси, банківська справа та страхування», Чернівецький національний університет імені Юрія Федьковича

Natalia Ostrovska

Doctor of Economics, Associate Professor, Associate Professor of the Department of Public, corporate finance and financial intermediation, Yuriy Fedkovych Chernivtsi National University

Veronica Vasechkina

6 th year graduate

specialty «Finance, Banking and Insurance» Yuriy Fedkovych Chernivtsi National University

У статті досліджено урізноманітнення продуктового асортименту банків. Визначено зарубіжний досвід диверсифрікації банківських послуг на прикладі Великобританії, Німеччини, Франції та інших країн. Визначено основні особливості обслуговування, які можуть застосовуватися в Україні. Висвітлено перспективи розвитку банківських послуг в Україні в умовах конкуренції. Обгрунтовано, що стратегія розвитку вітчизняного ринку банківських послуг повинна бути спрямована на розвиток існуючих секторів ринку та захоплення нових ніш, таких як сектор поштово-банківських послуд, що дозволить збільшити кількість клієнтів банку та зробити банківські послуги доступнішими. Розширення спектру послуг банку дасть значний поштовх для розвитку банківської системи України, а також сприятиме підвищенню конкурентоспроможності українських банків, як на національному, так і на міжнародному банківських ринках. ключові слова: банківська послуга, класифікація, традиційні банківські послуги, нетрадиційні банківські послуги, світовий досвід.

В статье исследовано разнообразие продуктового ассортимента банков. Определен зарубежный опыт диверсификации банковских услуг на примере Великобритании, Германии, Франции и других стран. Определены основные особенности обслуживания, которые могут применяться в Украине. Отражены перспективы развития банковских услуг в Украине в условиях конкуренции. Обосновано, что стратегия развития отечественного рынка банковских услуг должна быть направлена на развитие существующих секторов рынка и захват новых ниш, таких как сектор почтово-банковских услуг, что позволит увеличить количество клиентов банка и сделать более доступными банковские услуги. Расширение спектра услуд банка даст значительный толчок развитию банковской системы Украины, а также будет способствовать повышению конкурентоспособности украинских банков, как на национальном, так и на международном банковских рынках. Ключевые слова: банковская услуга, классификация, традиционные банковские услуги, нетрадиционные банковские услуги, мировой опыт.

The article examines the diversification of the product range of banks. It is substantiated that the modern money market is characterized by increasing domestic and intersectoral competition. The modern money market is characterized by increasing domestic and intersectoral competition. A new competitive environment has formed, where the market positions of commercial banks are under constant threat. The key factor in the functioning of banks in the money market is the diversification of banking products and services. A new competitive environment has formed, where the market positions of commercial banks are under constant threat. The key factor in the functioning of banks in the money market is the diversification of banking products and services. As world experience shows, specific legislation is not decisive for the development of leasing, the country's macroeconomic conditions dominate, state support for investment and leasing as an important form. The foreign experience of diversification of banking services on the example of Great Britain, Germany, France and other countries is determined. The main features of service that can be 
used in Ukraine are identified. Prospects for the development of banking services in Ukraine in conditions of competition are highlighted. It is substantiated that the strategy of development of the domestic market of banking services should be aimed at developing existing market sectors and capturing new niches, such as the postal banking sector, which will increase the number of bank customers and make banking services more accessible. The expansion of the bank's range of services will give a significant impetus to the development of Ukraine's banking system, as well as help increase the competitiveness of Ukrainian banks, both in the national and international banking markets. .

Key words: banking service, classification, traditional banking services, non-traditional banking services, world experience.

Постановка проблеми. Сучасний грошово-кредитний ринок характеризується посиленням внутрішньої та міжгалузевої конкуренції. Сформувалося нове конкурентне середовище, де ринкові позиції комерційних банків перебувають під постійною загрозою. Ключовим фактором фрункціонування банків на грошово-кредитному ринку стає диверсифікація банківських продуктів і послуг.

Аналіз останніх досліджень і публікацій. Дослідження проблематики урізноманітнення банківських послуг відображені в наукових працях таких авторів, як: В. Вовк [14], М. Дубини [1; 2], А. Жаворонка [3; 4], С. Кхалатур [6], В. Коваленко [7], Р. Лаврова [8], В. Маргасової [9], О. Мінця [10], О. Примостки [11], Б. Самородова [12], Н. Холявко [15], С. Шкарлета [13] та ін.

Виділення невирішених раніше частин загальної проблеми, котрим присвячується означена стаття. Незважаючи на значну кількість публікацій з даної проблематики, єдиного комплексного підходу до можливих перспектив розвитку банківських продуктів та послуг в Україні з урахуванням зарубіжного досвіду.

Формулювання цілей статті (постановка завдання). Метою даної роботи $є$ дослідження зарубіжного досвіду у сфері диверсифікації банківських послуг та перспективи їх розвитку в Україні.

Виклад основного матеріалу дослідження. В силу певних обставин, які пов'язані із рівнем довіри, платоспроможністю юридичних осіб, переслідуванням цілей надприбутковості банківського бізнесу, вітчизняні банки в більшій мірі орієнтовані на надання послуг фрізичним особам та підприємствам, що мають достатній запас оборотних коштів, натомість, фрінансуванню реального сектору економіки приділяється значно менше уваги. За таких обставин перед державою в особі НБУ та КМУ стоїть завдання пошуку шляхів активізації кредитування реального сектору економіки, а відповідно, створення нових і доступних банківських послуг для підприємств пріоритетних та суспільно важливих галузей економіки.

Тому необхідно врахувати досвід розвинутих країн у сфрері регулювання нетрадиційних послуг. Варто зауважити, що існують різні рівні забезпечення регулювання лізингу в зарубіжних країнах: країни, які мають спеціальні закони, що регулюють лізингові угоди (Франція, Італія); країни, які мають особливе спеціальне лізингове законодавство (Швеція, Австрія); країни, які не мають спеціальних законів і підзаконних актів, які регулювали б лізингові угоди (Німеччина, Данія, США) [1].

Наразі у лізинговій індустрії Великої Британії виокремлюють три види лізингових операцій: фрінансовий, оперативний та орендні угоди з опціоном купівлі, що передбачають придбання орендарем права власності на актив після виконання визначених контрактом умов. Контракт може також обумовлювати внесення чітко визначеної суми наприкінці оренди як викупного платежу. Водночас будь(яка лізингова угода, за британським законодавством, не може передавати права лізингоодержувачу на купівлю активу, що $\epsilon$ предметом лізингу.

Загалом у Великобританії (а також Данії, Hiдерландах) лізингова діяльність, як правило, законодавчо практично не обмежується. У Великобританії функціонують два галузевих об'єднання - Британська асоціація оренди та лізингу автотранспорту (British Vehicle Rental and Leasing Assocation) та Асоціація фрінансів та лізингу (Finance and Leasing Assiciation). Лізингові компанії, що є членами останньої, контролюють понад 92\% всього британського лізингового ринку.

Досвід Великобританії однозначно доводить ефрективність використання певних податкових стимулів для розвитку ринку лізингу, а також можливість ринкової економіки щодо саморегулювання ринку лізингових послуг в умовах доволі ліберального законодавства.

У Німеччині визначальним при оподаткуванні лізингових операцій також є економічний підхід. У випадках фрінансового лізингу податки за майно сплачує лізингоодержувач, якщо нормальний строк використання цього майна значно більший, ніж строк лізингової угоди. Лізингоодержувач має право на продовження угоди і опціон викупу майна, реалізуючи який він повинен сплатити лише збір, значно менший, ніж орендна плата або ціна купівлі. Якщо термін використання майна і термін договору співпадають, то діє це ж правило. Обов'язок лізингоодержувача сплачувати податки означає, що лише лізингоодержувач як господарюючий власник може користуватися правом на інвестиції з податковими пільгами.

Законодавством Німеччини, як і Швейцарії, 
передбачається, що у випадку лізингу власником майна залишається лізингодавець, а у випадку купівлі(продажу в розстрочку право володіння переходить до орендатора в момент оформлення угоди. Лізинг відрізняється від оренди та інших господарських відносин в основному економічно обгрунтованим розміром платежів, тобто договір лізингу як такий визначається не за економічними критеріями, а за формою на відповідність юридичним нормам.

Галузевим об'єднанням німецьких лізингодавців $є$ Федеральна асоціація лізингових компаній Німеччини, до якої станом на 01.01.2007 року входила 181 компанія (обсяги їх операцій становили 90\% усього лізингового бізнесу країни), з яких 155 компаній спеціалізувались тільки на лізингу обладнання та транспортних засобів, 9 - на лізингу нерухомості, 17 лізингодавців передавали в лізинг усі дозволені законодавством види активів, тобто вони були універсальними [1].

Німецький досвід ліберального законодавчого регулювання лізингу, в основному опосередкованими методами, довів свою ефективність в умовах поєднання ринкової економіки з державною підтримкою.

У Бельгії лізинг регулюється звичайним господарським та контрактним правом. Бельгійський уряд не підтримує фінансовий лізинг та не встановлює певних податкових пільг. У зв'язку з цим у Бельгії більшою мірою розвинуті інститути ринкового або саморегулювання лізингу. Зокрема, у Бельгії створена та активно діє Бельгійська Асоціація Лізингових Компаній, члени якої контролюють близько 90\% ринку лізингових послуг країни. На відмінну від Великобританії, у Бельгії (як і в Італії, Франції) обов'язковою умовою лізингової угоди є продаж майна після закінчення строку угоди за попередньо узгодженою ціною (опціон).

В Ірландії для стимулювання лізингу лізинговим компаніям надаються державні субсидії, можливість використовувати прискорений режим амортизації й інші пільги, що позитивно позначилося на лізинговому ринку. У результаті Ірландія стала світовим центром лізингу літаків.

Фактично у Франції угодами фінансового лізингу є угоди з опціоном викупу активу за залишковою вартістю (credit-bail). При цьому прямий лізинг забороняється, тобто виробнику майна не дозволяється виступати лізингодавцем. У Франції діяльність компаній, що спеціалізуються на фінансовому лізингу підлягає прямому державному регулюванню. Вони обов'язково реєструються у Банку Франції, отримують статус фрінансової установи і повинні виконувати певні нормативи, зокрема щодо мінімального розміру статутного капіталу.
Як показує світовий досвід, специфічне законодавство не $є$ визначальним для розвитку лізингу, домінують макроекономічні умови країни, державна підтримка інвестиційної діяльності й лізингу як важливої її форми.

Переглядаючи загальні тенденції ринку, можна укласти, що лідерство тієї чи іншої країни аж ніяк не визначається великою кількістю фракторингових компаній. Розподіл факторингових послуг в різних країнах проводиться по різних критеріям, а один і той же вид факторингу може носити різну назву у Великобританії, Італії та США.

Також на Заході популярна послуга реверсивного факторингу, при якому один фактор працює з усіма дебіторами певного постачальника. На відміну від Росії, Європа вже починає використовувати передпоставче фінансування. У цьому випадку оплата товару здійснюється фактором у момент отримання замовлення, коли дебіторська заборгованість, по суті, ще не виникла, так як продукція ще не була відвантажена.

Так, у Європі, США, Японії, Китаї і в інших країнах були створені спеціалізовані банки розвитку, які надали істотну підтримку у відновленні економіки цих країн. Їх основне завдання полягало в тому, щоб кошти з державних джерел спрямовувати в ключові сфери національної економіки. Всі ці країни мали досить досконалі системи банків розвитку, які зіграли надзвичайно важливу роль у розвитку національної економіки країн, заповнивши десіцит коштів комерційних структур. У нових індустріальних країнах - Республіці Корея, Сінгапурі, Бразилії - банки розвитку також мають істотне значення в економічному житті.

Сучасне законодавство Федеративної Республіки Німеччина розглядає факторинг як операцію купівлі-продажу боргових зобов'язань, що виникають в процесі обігу товарів або надання послуг. Факторинг вважається торговою, а не кредитною операцією. У разі, якщо організації, що спеціалізуються на наданні фракторингових послуг, мають статус банків, то на них накладається ряд додаткових обмежень. В інших випадках регулюють обмеження факторингової діяльності відсутні. В даний час у ФРН діє близько 60 факторингових організацій. Факторинг широко використовується малими і середніми підприємствами більш ніж в 30 галузях промисловості.

У Бельгії під фракторингом розуміється форма кредитування, що виражається в інкасуванні дебіторської заборгованості клієнта, тобто покупка спеціалізованою фінансовою компанією або банком усіх грошових вимог клієнта до боржника. Спеціальних вимог щодо отримання дозволів або акредитацій для занять факторингом в бельгійському законодавстві не передбачено. Займаються факторингом бельгійські банки і страхові 
компанії отримують лише дозволу на здійснення відповідно банківської і страхової діяльності.

В даний час в Бельгії діє ряд спеціалізованих факторингових організацій, які, як правило, $€$ дочірніми товариствами відомих міжнародних факторингових компаній. Слід також зазначити, що практично всі діючі в Бельгії банки і суспільства по страхуванню кредитів пропонують своїм клієнтам послуги фракторингу. Частка фракторингу у ВВП становить близько 3\% [3].

Досвід окремих країн свідчить на користь того, що ринок факторингу краще розвивається, коли законодавче регулювання мінімально. В цілому, як показує зарубіжний досвід, ринок факторингу дуже перспективний і динамічно розвивається сегмент економіки. У багатьох економічно розвинених країнах діяльність 3 фінансування під відступлення грошової вимоги не підлягає жорсткому нормативному регулюванню, і на її здійснення не потрібно спеціальних дозволів (ліцензій). Більш того, проведений аналіз міжнародного законодавства дозволяє зробити висновок, що чим більш врегульований факторинг законодавцем, тим він менш розвинений.

Іншим важливим стратегічним напрямком розвитку вітчизняного ринку банківських послуг $€$ впровадження інновацій у діяльність банків, адже інноваційні технології в наш час відіграють дуже важливу роль. Нове бачення розвитку сфери банківських послуг ґрунтується на концепції «банку майбутнього». При створенні банку майбутнього інноваційні технології в сфері банківських послуг - це такі технології, яким притаманний «стратегічний ефект» приросту клієнтської бази, зацікавленні значимих персон, зменшення витрат на здійснення банківських операцій при оптимальному рівні операційного ризику і операційних затрат.

Специфічною рисою України, на думку банківських спеціалістів, є те, що тут розвиток ринку інноваційних банківських продуктів стримує відсутність попиту на них. Багатьом українським споживачам у принципі чуже сприйняття банку як фінансового радника і консультанта, тому українські банки, як і банки інших пострадянських країн, більшою мірою концентруються на інноваціях, що спрямовані на створення нових потреб, активно запозичуючи при цьому зарубіжний досвід. Також характерним для банківських інновацій в Україні $€$ те, що вони найчастіше створюються на вимогу корпоративних клієнтів. При цьому основна увага приділяється не новизні продукту, а його унікальності для клієнта, підвищенню зручності та привабливості для клієнта.

Відтак, задля успішної інноваційної діяльності та створення інноваційних продуктів вітчизняним банкам, котрі прагнуть підвищення своєї конкурентоспроможності та іміджу, необхідно розробити інноваційну стратегію розвитку банку. Таким чином, інноваційна стратегія виконує три функції: по-перше, надає дію на створення конкурентної стратегії, визначаючи сфери поза упровадження інновацій (ринки, клієнтські групи, канали збуту, технології тощо); по-друге, формує склад портфеля інноваційних проектів; по-третє, встановлює методи управління інноваційною діяльністю. Вона сприяє органічному зростанню банку, максимізує можливості існуючих бізнесів і організовує нові, підвищує респонсівность фінансового інституту, створює нові потоки доходів [2].

У сучасних умовах банки використовують різні варіанти організаційної структури та підходи до забезпечення інноваційної діяльності. У банку може бути створено окремий автономний підрозділ, яке відноситься до мідл-офісу, підпорядковується інноваційних топ-менеджеру і має постійно працюючої й персонал. Іншим варіантом може бути формування підрозділів з аналогічними завданнями в функціональних службах банку (маркетингу, стратегічного розвитку і тому подібне), які в процесі роботи контактують з різними відділами для здійснення певних аспектів процесу створення і впровадження нововведень. Для реалізації окремих інноваційних проектів можливе створення внутрішніх венчурних підрозділів, яким надаються достатні повноваження для вирішення поставлених завдань.

Серед інших актуальних інноваційних пропозицій на вітчизняному ринку банківських послуг традиційно є Інтернет та мобільний банкінг.

В сорері Інтернет банкінгу можна запропонувати досвід компанія Apple, яка презентувала на своєму офіційному сайті програму IChat, за допомогою якої користувач через Internet може зустрітися з працівником банку по відео виклику. Ця інноваційна послуга буде називатись відеобанкінгом. Вона буде доступна цілодобово. За ії̈ допомогою клієнт може отримати консультацію банківського працівника 3 будь-якого питання, яке його цікавить [4].

Більшість світових аналітиків сьогодні схиляються до того, що найперспективнішою технологією для реалізації мобільних платежів є технологія NFC. На підтримку цієї технології виступили і найбільші гравці міжнародних платіжних систем (МПС), в тому числі VISA і Master Card.

Використовуючи спеціальний додаток, власники телефонів з NFC можуть оплачувати покупки простим піднесенням телефону до спеціального електронного пристрою, що зчитує. Практично всі провідні виробники мобільних телефонів випустили зразки телефонів з підтримкою технології NFC. Така інновація зменшить витрати банку на випуск пластикових карт, а також збільшить можливості клієнта щодо користуван- 
ня банківськими послугами, адже разом із відповідними додатками для смартфонів, клієнти фрактично отримають банк в кишені.

Банківські послуги потужний інструмент соціально-економічного розвитку. Для української економіки в даний час істотним чинником подальшого зростання $є$ роздрібний банківський бізнес, потенціал якого в частині забезпечення банківської системи довгостроковим стійким ресурсом, створення можливостей прискорення оборотності капіталу, а також задоволення попиту населення на дорогі товари за допомогою кредитування залишається дуже високим. Однак, основною перешкодою на шляху досягнення головної мети роздрібного бізнесу - забезпечення масових продажів при мінімальному рівні витрат сьогодні стоїть висока вартість розширення мережі банківського обслуговування.

Сьогодні Державне підприємство «Укрпошта» - найбільша роздрібна мережа в країні, що налічує близько 14 тисяч відділень, що покриває всі регіони, в тому числі важкодоступні райони та сільську місцевість, де пропозиція банків або вкрай обмежена, або повністю відсутній. Даний фракт дозволяє розглядати пошту як унікальний канал просування банківських послуг.

У світі існує безліч прикладів успішної співпраці пошти і банків. Поштово-банківська діяльність представлена практично на всій території Європи і в ряді країн Азії. Практика показує, що відносини пошти і банків формуються по різному з урахуванням відмінностей у законодавчому регулюванні поштового та банківської діяльності, а також національних особливостей формування даних галузей. В одних країнах пошта самостійно надає фрінансові послуги і співпрацює з банками, виступаючи в ролі їх агента та надаючи послуги банків за певний відсоток. До таких країн можна віднести Італію, Швейцарію, донедавна Японію та ін. В інших країнах поштово-банківські послуги надаються і контролюються поштою, а спеціально створеним поштовим банком. Система поштових банків характерна для таких країн, як Німеччина, Англія, Нідерланди, Скандинавські країни та ін. [5].

Населення України, яке проживає у сільській місцевості не може похвалитися таким високим рівнем фрінансової грамотності, як населення перелічених вище країни, а тому поштово-банківські послуги, на початковому етапі розвитку, повинні мати роздрібний характер, а самі поштові відділення повинні сприяти підвищенню рівня фрінансової грамотності серед сільського населення. Таким чином, банкам доцільно спільно з Укрпоштою розробити механізм надання роздрібних поштово-банківських послуг, а зокрема залучення депозитів (в першу чергу ощадних), надання споживчих кредитів, грошові перекази, створення можливостей зняття готівки з карткових рахунків (що пов'язано із відсутністю банкоматів на селі). Окрім цього, доцільно при видачі пенсій пенсіонерам, виплати соціальної допомоги проводити роз'яснювальну роботу щодо розвитку фрінансової грамотності. Така робота може вестися через розповсюдження спеціальних газет, які серед старшого населення мають високу популярність.

Висновки 3 цього дослідження і перспективи подальших розвідок у даному напрямку. Таким чином стратегія розвитку вітчизняного ринку банківських послуг повинна бути спрямована на розвиток існуючих секторів ринку та захоплення нових ніш, таких як сектор поштово-банківських послуг, що дозволить збільшити кількість клієнтів банку та зробити банківські послуги доступнішими. Розширення спектру послуг банку дасть значний поштовх для розвитку банківської системи України, а також сприятиме підвищенню конкурентоспроможності українських банків, як на національному, так і на міжнародному банківських ринках.

\section{БІБЛІОГРАФІЧНИЙ СПИСОК:}

1. Дубина М. В. Економічна суть та види фрінансових послуг. Світ фрінансів. 2016. №3(48). С. 124-135.

2. Dubyna M., Zhavoronok A., Kudlaieva N. \& Lopashchuk I. Transformation of Household Credit Behavior in the Conditions of Digitalization of the Financial Services Market. Journal of Optimization in Industrial Engineering. 2021. 14(1). P. 97-102. https://doi.org/10.22094/JOIE.2020.677835

3. Жаворонок А. Міжнародний досвід фрункціонування ринку кредитних послуг. Економічний дискурс. 2020. 1. С. 68-77. https://doi.org/10.36742/2410-0919-2020-1-8

4. Жаворонок А.В. Проблеми вдосконалення механізму банківського кредитування як засобу стимулювання розвитку ринку кредитних послуг в Україні. Вісник економічної науки України. 2020. № 1 (38). С. $196-201$. https://doi.org/10.37405/1729-7206.2020.1(38).196-201

5. Жаворонок А. Тенденції розвитку ринку кредитних послуг в Україні. Галицький економічний вісник. 2020. 63 (2). C. 145-155. https://doi.org/10.33108/galicianvisnyk_tntu2020.02.145 6. Khalatur S., Zhylenko K., Masiuk Y., Velychko L. \& Kravchenko M. (2018). Assessment of bānk lending diversification in Ukraine. Banks and Bank Systems. 2018. 13(3), 141-150. https://doi.org/10.21511/bbs.13(3).2018.14

7. Kovalenko V. \& Kerimov A. Internarial standards of financial support stability of the banking system. Economic and Social Development. 37 th International Scientific Conference on Economic and Social Development - "Socio Economic Problems of Sustainable Development". Book of Proceedings. 2019. P. 938-947.

8. Lavrov R., Beschastnyi V., Nikolenko L., Yousuf A., Kozlovskyi S., Sadchykova I. Special aspects of the banking 
institutions rating: a case for Ukraine. Banks and Bank Systems. 2019. 14(3). P. 48-63. https://doi.org/10.21511/ bbs.14(3).2019.05

9. Margasova V., Muravskyi O., Vodolazska O., Nakonechna H., Fedyshyn M. \& Dovgan L. Commercial Banks as a Key Element in Regulating Cash Flows in the Business Environment. International Journal of Recent Technology and Engineering. 2019. 8 (4). C. 4537-4543. https://doi.org/10.35940/ijrte.d8465.118419

10. Mints O., MarhasovaV., Hlukha H., Kurok R., \& Kolodizieva T. Analysis of the stability factors of Ukrainian banks during the 2014-2017 systemic crisis using the Kohonen self-organizing neural networks. Banks and Bank Systems. 2019. 14(3). P. 86-98. https://doi.org/10.21511/bbs.14(3).2019.08

11. Prymostka O. \& Prymostka L. Ukrainian banking system efficiency after double reducing of the number of bank institutions. Banks and Bank Systems. 2018. 13(4). P. 51-60. https://doi.org/10.21511/bbs.13(4).2018.05

12. Samorodov B.V., Azarenkova G.M., Golovko O.G., Miroshnik O.Yu. \& Babenko M.V. Credit risk management in the bank's financial stability system. Financial and credit activity: problems of theory and practice. 2019. 4 (31). P. 301-310. https://doi.org/10.18371/fcaptp.v4i31.190920

13. Shkarlet S., Dubyna M., Zhuk O. Determinants of the financial services market functioning in the era of the informational economy development. Baltic Journal of Economic Studies. 4(3). 2018. P. 349-357. https://doi. org/10.30525/2256-0742/2018-4-3-349-357

14. Shkarlet S., Dubyna M., Vovk V., \& Noga M. (2019). Financial service markets of Eastern Europe: a compositional model. Economic Annals-XXI, 176 (3-4), 26-37. https://doi.org/10.21003/ea.V176-03

15. Zhavoronok A., Kholiavko N. Banking system of Ukraine: trends and prospects of development. Modern Science - Moderní věda. 2020. No. 10. Pp. 129-142.

\section{REFERENCES:}

1. Dubyna, M. V. (2016) Ekonomichna sutj ta vydy finansovykh poslugh [Economic nature and types of financial services]. Svit finansiv - The world of finance. 3(48). 124-135. (in Ukrainian).

2. Dubyna, M., Zhavoronok, A., Kudlaieva, N., \& Lopashchuk, I. (2021) Transformation of Household Credit Behavior in the Conditions of Digitalization of the Financial Services Market. Journal of Optimization in Industrial Engineering. 14(1). Pp. 97-102. https://doi.org/10.22094/JOIE.2020.677835

3. Zhavoronok, A. (2020) Mizhnarodnyi dosvid funktsionuvannia rynku kredytnykh posluh [International experience in the operation of the credit services market]. Ekonomichnyi dyskurs - Economic discourse. 1. 68-77. https://doi. org/10.36742/2410-0919-2020-1-8 (in Ukrainian).

4. Zhavoronok, A. V. (2020) Problemy vdoskonalennia mekhanizmu bankivskoho kredytuvannia yak zasobu stymuliuvannia rozvytku rynku kredytnykh posluh $v$ Ukraini [Problems of improving the mechanism of bank lending as a means of stimulating the development of the credit services market in Ukraine]. Visnyk ekonomichnoi nauky Ukrainy - Bulletin of Economic Science of Ukraine. 1(38). 196-201. https://doi.org/10.37405/1729-7206.2020.1(38).196-201 (in Ukrainian).

5. Zhavoronok, A. (2020). Tendentsii rozvytku rynku kredytnykh posluh v Ukraini [Trends in the development of the credit services market in Ukraine]. Halytskyi ekonomichnyi visnyk - Galician Economic Bulletin. 63(2). 145-155. https://doi.org/10.33108/galicianvisnyk_tntu2020.02.145 (in Ukrainian).

6. Khalatur, S., Zhylenko, K., Masiuk, Y., Velychko, L. \& Kravchenko, M. (2018) Assessment of bank lending diversification in Ukraine. Banks and Bank Systems. 13(3). 141-150. https://doi.org/10.21511/bbs.13(3).2018.14

7. Kovalenko, V., \& Kerimov, A. (2019). Internarial standards of financial support stability of the banking system. Economic and Social Development. 37 th International Scientific Conference on Economic and Social Development - "Socio Economic Problems of Sustainable Development". Book of Proceedings. 938-947.

8. Lavrov, R., Beschastnyi, V., Nikolenko, L., Yousuf, A., Kozlovskyi, S., \& Sadchykova, I. (2019) Special aspects of the banking institutions rating: a case for Ukraine. Banks and Bank Systems. 14(3). 48-63. https://doi.org/10.21511/ bbs.14(3).2019.05

9. Margasova, V., Muravskyi, O., Vodolazska, O., Nakonechna, H., Fedyshyn, M., \& Dovgan, L. (2019) Commercial Banks as a Key Element in Regulating Cash Flows in the Business Environment. International Journal of Recent Technology and Engineering. 8 (4). 4537-4543. https://doi.org/10.35940/ijte.d8465.118419

10. Mints, O., Marhasova, V., Hlukha, H., Kurok, R., \& Kolodizieva, T. (2019) Analysis of the stability factors of Ukrainian banks during the 2014-2017 systemic crisis using the Kohonen self-organizing neural networks. Banks and Bank Systems. 14(3). 86-98. https://doi.org/10.21511/bbs.14(3).2019.08

11. Prymostka, O. \& Prymostka, L. (2018) Ukrainian banking system efficiency after double reducing of the number of bank institutions. Banks and Bank Systems. 13(4). 51-60. https://doi.org/10.21511/bbs.13(4).2018.05

12. Samorodov, B. V., Azarenkova, G. M., Golovko, O. G., Miroshnik, O. Yu., \& Babenko, M. V. (2019). Credit risk management in the bank's financial stability system. Financial and credit activity: problems of theory and practice. 4(31). 301-310. https://doi.org/10.18371/fcaptp.v4i31.190920

13. Shkarlet, S., Dubyna, M., \& Zhuk, O. (2018) Determinants of the financial services market functioning in the era of the informational economy development. Baltic Journal of Economic Studies. 4(3). 349-357. https://doi. org/10.30525/2256-0742/2018-4-3-349-357

14. Shkarlet, S., Dubyna, M., Vovk, V., \& Noga, M. (2019) Financial service markets of Eastern Europe: a compositional model. Economic Annals-XXI. 176 (3-4). 26-37. https://doi.org/10.21003/ea.V176-03

15. Zhavoronok, A., \& Kholiavko, N. (2020) Banking system of Ukraine: trends and prospects of development. Modern Science - Moderní věda. 10. 129-142. 